\title{
BIOCHEMICAL MARKERS OF BONE COLLAGEN TYPE I METABOLISM
}

\author{
O. V. ZAITSEVA, S. G. SHANDRENKO, M. M. VELIKY \\ Palladin Institute of Biochemistry, National Academy of Sciences of Ukraine, Kyiv; \\ e-mail: Zaitseva_OV@ukr.net
}

This review focuses on the analysis of diagnostic value of the major bone remodeling markers, in particular synthesis and degradation markers of collagen type I. These include carboxy-and aminoterminal telopeptide, carboxy- and aminoterminal propeptide of procollagen type I, hydroxyproline, hydroxylysine, pyridinoline and deoxypyridinoline. Their measurement allows evaluating the structural and functional conditions and also the rate of metabolic processes in the bone tissue. The advantages and disadvantages of determination of these markers in the condition of different bone diseases were examined. It is shown that determination of bone collagen type I metabolism markers is the most informative for assessment of bone resorption, formation and turnover.

Key word s: collagen type I, the markers of collagen synthesis and degradation, bone.

$\mathrm{N}$ umerous bone diseases, such as osteoporosis, osteomalacia, Paget's disease, are associated with metabolism disorders and accompanied by substantial changes in biochemical markers of bone remodeling [1]. For diagnosing and monitoring of bone diseases specific enzymes activities, mineral and organic components content in blood are most commonly assessed. These components enter the bloodstream in the process of their synthesis by osteoblasts and osteoclasts or their formation in the osteoclasts as a result of mediated bone resorption. Thus, changes in calcium, inorganic phosphate, osteocalcin, 25-hydroxycholecalciferol $\left(25 \mathrm{OHD}_{3}\right)$ levels [2], alkaline and tartrate-resistant acid phosphatase activities [1], collagen type I metabolism products such as carboxy- and aminoterminal propeptides of procollagen type I, hydroxyproline, hydroxylysine, pyridinoline, deoxypyridinoline in serum can reflect bone state.

Clinically the measurement of total alkaline phosphatase (ALP) activity and its bone isoenzyme are the most commonly used markers of bone metabolism disturbances. ALP is constitutively expressed in osteoblasts (bone forming cells) which catalyzes the phosphate ester hydrolysis during the osteosynthesis and provides phosphate-ion transfer onto organic components of bone pericellular matrix. ALP is also involved in the process of phosphates elevation and their transportation to the site of the hydroxyapatite crystals synthesis in bone. Cata- lytic activity of ALP depends on phosphate concentration and related to histocytological changes in the bone formation parameters [1, 3].

Three main ALP isoenzymes have been identified: placental, intestinal and isoenzyme specific for bone (B-ALP), liver and kidneys. Bone and liver equally contribute to ALP circulation. The intestinal mucosa makes it less. Methods that based on heat stability, sensitivity to carbamide, peculiarities of electrophoretic mobility, hydrocarbon composition and immunochemical specificity are used for the separate determination of individual isoenzymes. In particular, bone isoenzyme is thermolabile and BALP activity is completely inhibited in response to heat at $56^{\circ} \mathrm{C}$ for $10 \mathrm{~min}$. Residual activity becomes below $20 \%$ of initial activity after heating serum sample that represents partial bone isoenzyme activity [4, 5].

ALP activity elevation, mainly due to bone isoenzyme, during extensive bone growth and in pathologic conditions that is accompanied by abnormalities in bone mineralization is observed. There are osteoporosis, osteomalacia, vitamin D deficiency, aluminium intoxication, hypophosphatemic rickets, hyperthyroidism, myocardial infarction, etc. This effect can also be associated with long-term use of nonsteroidal anti-inflammatory drugs (allopurinol, oral hypoglycemic agents) [3, 5].

Osteocalcin (bone Gla-protein) is a non-collagenous bone matrix protein which is primarily 
synthesized by mature osteoblasts, odontoblasts and hypertrophic chondrocytes. Osteocalcin has been found only in bones and in dentin. Three $\gamma$-carboxyglutamate residues in osteocalcin provide high $\mathrm{Ca}^{2+}$-ion binding affinity and stabilize the osteocalcin $\alpha$-structure. This allows osteocalcin binding with the hydroxyapatite. Theoretically, osteocalcin blood level reflects bone formation. However, owing to post-translational metabolism one-third of osteocalcin is presented in the intact protein form, onethird in the large N-terminal fragment form and onethird in the form of medium and small C-terminal fragments. These immunoreactive osteocalcin fragments are released into the blood and can characterize bone resorption process $[6,7]$.

Osteocalcin is a valid bone remodeling marker in case of coupling between bone formation and resorption. When remodeling process is disturbed, osteocalcin level is tightly related only to osteogenesis. It occurs in conditions of long-term use of corticosteroids, cancer-associated hypercalcemia, etc. It is known that osteocalcin level is decreased in hypothyroidism, hypoparathyroidism, and myelomatosis. Osteocalcin in patients with acute lymphoblastic leukemia is decreased two times as compared with healthy children [7]. Serum osteocalcin elevation is observed in primary hyperparathyroidism, hyperthyroidism, Paget's disease, chronic kidney disease, postmenopausal osteoporosis [5]. However, osteocalcin is a widely used marker of bone formation but its short half-life in blood ( 10 min) and fast excretion through kidneys should be taked into account [5].

Five acid phosphatase (AP) isoenzymes have been found. There are bone-, prostate-, platelets-, erythrocyte- and spleen-specific ones. Tartrate-resistant acid phosphatase bone isoenzyme (TRAP) is produced only by osteoclasts. In this case TRAP is a specific marker of osteoclasts activity and bone resorption. Methods for total AP determination and its isoenzymes activities have low specificity. Nevertheless, inhibitive capability of TRAP by tartrate gives an opportunity to distinguish its activity from activities of other phosphatases in particular erythrocyte- and prostate-specific isoenzymes. TRAP activity measurement is also accompanied by electrophoretic separation and immunoenzyme analysis for accuracy improving. The use of TRAP as a marker of bone resorption is limited by its instability in frozen serum and plasma samples, as well as by the presence of an enzyme inhibitor in blood. Additional difficulties are caused by the blood circulating calcium-binding TRAP form. That is why it should be separated before measurement $[4,5,8]$.

TRAP activity is elevated in patients with bone metastasis and other diseases accompanied by extensive bone destruction, such as osteomalacia, hyperthyroidism, Paget's disease, long-term glucocorticoid therapy. Like other resorption markers TRAP activity is increased after oophorectomy or the menopause [5].

Despite the fact that earlier discussed clinical markers are widely used in diagnostics, they are not universal for the bone conditions assessment. For an adequate diagnostics and monitoring of bone disease treatment efficacy special attention is paid to the investigation of type I collagen fragments content in blood or urine as markers of bone formation and resorption. Because collagen is the major bone tissue protein and its amino acid composition differs from other proteins in connective tissues, biochemical collagen metabolism markers are specific. These markers allow characterizing the bone metabolic processes in normal and pathological conditions. It is well known that various diseases can lead to structural changes in collagen. E.g., bone collagen in patients with leukemia has different amino acid composition, surface charge, content of covalently bounded carbohydrate residues and polypeptide chain length of molecule $\alpha$-components compared with normal collagen [9]. The substantial changes in collagen are specific not only for bone pathologies, but also for other diseases. This makes collagen an important subject for research.

Numerous collagen molecule fragments entering the bloodstream during the bone metabolic lesion have been discovered. Some of them are well studied and widely used in clinical practice, while the other are potentially important but require a more detailed research. Carboxy- and aminoterminal telopeptide, carboxy- and aminoterminal propeptide procollagen type I, pyridinoline, deoxypyridinoline, hydroxiproline and hydroxylisine are the main biochemical markers of collagen type I metabolism. The appropriateness of these markers determination depends on the peculiarities of pathologies' development, difficulties of laboratory technique and informative capacity of obtained data. Therefore, this review is focused on the analysis of the advantages and disadvantages in clinical using of bone remodeling markers (resorption and formation) mainly of collagen type I metabolism markers in various bone pathologies. 


\section{Collagen as a major structural element of bone}

Bone tissue is one of the connective tissue types. It performs important functions in the body, such as protection and support for internal organs, assisting in body movement, reservoir for calcium, inorganic phosphate and other minerals, the bone marrow also performs blood cell production and functioning of the immune system [10]. Bone has a complex structure. Its extracellular matrix consists of $35 \%$ organic and $65 \%$ mineral matrix. Inorganic matrix is predominantly represented by body calcium (99\%), phosphorus (87\%), magnesium ( 60\%), sodium and other elements (25\%). Bone calcium and phosphorus are presented in the hydroxyapatite $\mathrm{Ca}_{10}\left(\mathrm{PO}_{4}\right)_{6}(\mathrm{OH})_{2}$ mineral form (in the range of 60 $65 \%)[10,11]$. Organic bone matrix is mainly composed by various collagen types (I, V, VI, XIV and XXIV) [12]. Collagen type I is the most abundant among proteins, making up 95\% of the total bone collagen and $80 \%$ of the whole bone protein $[13,14]$. Besides collagen type I, there are about 200 noncollagenous proteins, such as glycoproteins, proteoglycans, integrin binding proteins, fibronectin, fibromodulin and enzymes, such as alkaline and acid phosphatases which are presented in the bone matrix $[10,15]$.

Bone collagen (type I) is a right-handed helical molecule that consists of three polypeptide chains. There are two identical $\alpha_{1}$-chains and one $\alpha_{2}$-chain ([a1(I) $\left.]_{2} \alpha 2(\mathrm{I})\right)$ (Fig. 1) [16-18].

The collagen helix structure differs from the structure of other $\alpha$-helical proteins. Thus, collagen helix has 3 amino acid residues per turn unlike 3.6 in $\alpha$-helix. The helical pitch is $0.9 \mathrm{~nm}$ in contrast to the $0.54 \mathrm{~nm}$ in $\alpha$-helix [12]. So, the primary collagen helix is more elongated and less twisted. The amino acid composition of collagen is atypical for proteins. Every third amino acid in the chain is glycine (its content is $33-35 \%$ ). Collagen is also characterized by high content of proline and hydroxyproline (20-21\%). These amino acids prevent classic $\alpha$-helix formation and give the collagen chain rigid and bent conformation [12, 17].

A major part of the collagen type I $\left(M_{r} 300 \mathrm{kDa}\right)$ in mammals (Fig. 1) is synthesized by fibroblasts and osteoblasts on polyribosomes, which bound to membranes of rough endoplasmic reticulum, as a high-molecular-weight, functionally inactive precursor procollagen type I. The precursor molecule ( $\left.\mathrm{M}_{\mathrm{r}} 450 \mathrm{kDa}\right)$ has $\mathrm{N}$-(amino-) and $\mathrm{C}$-(carboxy-) terminal nontriple helix propeptides (PINP and PICP) on each of the three chains [19-21]. These terminal propeptides are presented in the form of globular or linear domains which play a significant role in the assembly of the three $\alpha$-chains into the triple collagen monomers [22].

The newly synthesized procollagen molecule is transported to the Golgi apparatus and secreted via secretory granules into the extracellular space. The last stages of the procollagen extracellular modification, specifically cleavage of $\mathrm{N}$ - and $\mathrm{C}$-terminal propeptides with forming tropocollagen, take place in the extracellular matrix. This process is catalyzed by specific $\mathrm{Zn}^{2+}$-dependent metalloproteinase $\mathrm{N}$ - and C-procollagen peptidase [13, 23]. Formed tropocollagen can polymerize and aggregate into fibrils to form active collagen form. Thus, tropocollagen monomers are assembled along collagen fibrils in collagen bundles form which are located from each other at a distance $64 \mathrm{~nm}$. It is considered that these spaces play a significant role in the mineralization. They are

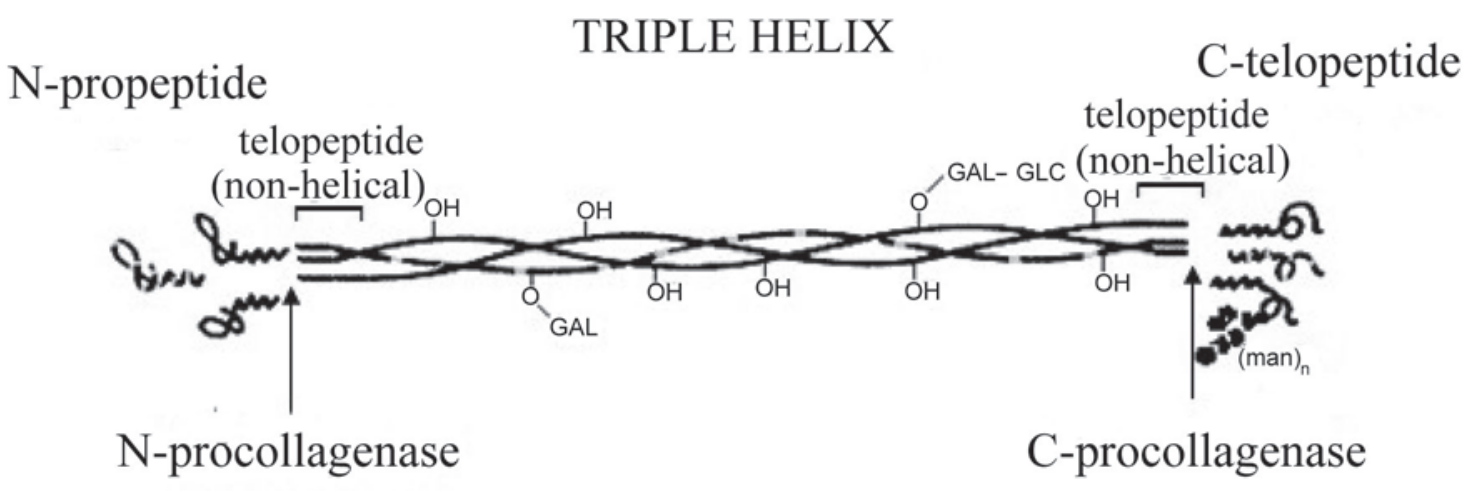

Fig. 1. Molecular structure of fibrillar collagen type I (adapted to [13]) 
the initial sites for mineral compounds' deposition. Formed initial crystals are the centers of mineralization and hydroxiapatite deposition [12]. During collagen fibrils' formation tropocollagen molecules bound each other by unusual covalent cross-links. The cross-links' formation is initiated by oxidation of lysine and hydroxilysine side chains amino groups to aldehyde groups with allysine and hydroxiallysine formation. These reactions are catalyzed by coppercontaining lysyl oxidase enzyme [13, 24, 25].

Owing to extremely large quantities of formed cross-links, bundled and twisted collagen fibrils form a 3D network, which is filled up with other substances of the extracellular matrix and makes the tissues sturdier. Collagen posttranslational modifications are very important for mineralization process. Thereby, the mineral components deposition occurs only if collagen has a specific structure with available reactive groups which can act as sites of crystallization [13].

\section{Biochemical markers of bone collagen type I synthesis and degradation}

All skeletal system diseases are accompanied by various bone metabolism disorders. Standard clinical procedures do not allow in full to characterize the actual bone metabolism because most of them are not appropriate for immediate bone assessment. Therefore, biochemical markers of collagen type I metabolism determination in dynamics can be determinant for diagnosis or assessment of therapy effectiveness. Markers of collagen type I metabolism have been classified as shown on Table 1. There are synthesis and degradation markers. Degradation markers include hydroxyproline (HYP), hydroxylysine (HYL), pyridinoline (PYD), deoxypyridinoline (DPD), collagen type I N-terminal telopeptide (NTX), collagen type I C-terminal telopeptide (CTX). Whereas, procollagen type I C-terminal propeptide (PICP) and procollagen type I N-terminal propeptide (PINP) are the markers of synthesis. These markers reflect changes in bone cells functioning and show the overall rate of bone collagen metabolism in pathology [26]. Synthesis and degradation markers differ in their specificity and ability to detect. Various methods can be used to identify and measure their levels. There are radio immuno assay (RIA), enzyme-linked immunosorbent assay (ELISA), high performance liquid chromatography (HPLC), electrochemiluminescence immunoassay (ECLIA), immunochemiluminometric assay
(ICMA). ELISA is preferred in clinical practices for measurement these markers in blood or urine (Table 1) [26, 27].

Level of bone collagen remodeling markers in blood and urine is affected not only by bone metabolic rate, but also by excretion rate of collagen type I metabolism markers. Thus, we have a question, which of the markers gives the most reliable and accurate characteristic of bone state. A more detailed study of each marker will allow making certain conclusions about their experimental and clinical usage [26].

\section{Markers of collagen type I degradation}

\section{Hydroxyproline (HYP)}

Despite numerous disadvantages, the oldest and the most commonly used method for collagen metabolism assessment is HYP level determination in the urine. HYP is approximately $13 \%$ of all collagen amino acids [28]. HYP synthesis occurs in the condition of collagen mRNA translation on ribosome. It is catalyzed by prolyl-4-hydroxylase. This iron-containing enzyme is bound with endoplasmic reticulum membrane. Prolyl hydroxylase has $\alpha$-ketoglutarate $(\alpha-K G)$ as a co-substrate, which is decarboxylated and converted to succinate (Fig. 2). In hydroxylation process iron of prolyl-4-hydroxylase active site $\left(\mathrm{Fe}^{2+}\right)$ gives off electrons and is oxidized to $\mathrm{Fe}^{3+}$. Reduction of $\mathrm{Fe}^{3+}$ to $\mathrm{Fe}^{2+}$ is provided by ascorbic acid.

Proline hydroxylation occurs on the forming polypeptide chain up to its releasing from the ribosome. It is found that attaching a hydroxyl group to proline is necessary for collagen triple helix stabilization and its transportation out of cells. It is also known that released HYP after collagen breakdown process cannot be directly reutilized for protein synthesis [29]. Hydroxyproline content is related to calcium bloodstream releasing and bone resorption process in various pathologies, such as Paget's disease, osteoporosis, osteomalacia etc (Calvo et al. 1996) [30].

The most commonly used method for HYP specific determination in clinics is based on HYP oxidation by hydrogen peroxide in alkaline medium with the $\mathrm{Cu}^{2+}$ presence. Addition of $p$-dimethylaminobenzaldehyde after acidification leads to generation of the pink color [31].

HYP exists in biological fluids in various forms. Approximately $90 \%$ of HYP which released during collagen breakdown (especially during bone 
Ta b le 1. Synthesis and degradation markers of collagen type I

\begin{tabular}{|c|c|c|c|}
\hline Marker and its specificity & Tissue origin & $\begin{array}{l}\text { Biological } \\
\text { samples }\end{array}$ & $\begin{array}{l}\text { Analytical } \\
\text { method }\end{array}$ \\
\hline \multicolumn{4}{|c|}{ Markers of collagen degradation } \\
\hline $\begin{array}{l}\text { Hydroxyproline (HYP); specific for all fibrillar collagens } \\
\text { and collagen proteins, including elastin; found in newly } \\
\text { synthesized and mature collagen }\end{array}$ & $\begin{array}{l}\text { Bone, skin, } \\
\text { cartilage, } \\
\text { soft tissues }\end{array}$ & Urine & $\begin{array}{l}\text { Colorimetry, } \\
\text { HPLC }\end{array}$ \\
\hline $\begin{array}{l}\text { Hydroxylisine-glycosides (Hyl-Glyc); specific for } \\
\text { collagens and collagen proteins; glucogalactosyl- } \\
\text { hydroxilysine is highly contained in soft tissue collagens } \\
\text { and Clq; galactosyl-OHLys is highly contained in skeletal } \\
\text { collagen }\end{array}$ & $\begin{array}{l}\text { Bone, skin, } \\
\text { soft tissues }\end{array}$ & Urine & $\begin{array}{l}\text { HPLC, } \\
\text { ELISA }\end{array}$ \\
\hline $\begin{array}{l}\text { Pyridinoline (PYD, Pyr); high concentration is observed } \\
\text { in cartilage and bone collagen; not found in skin, found } \\
\text { only in mature collagen }\end{array}$ & $\begin{array}{l}\text { Bone, tendon, } \\
\text { cartilage, } \\
\text { blood vessels }\end{array}$ & $\begin{array}{l}\text { Urine, } \\
\text { serum }\end{array}$ & $\begin{array}{l}\text { HPLC, } \\
\text { ELISA }\end{array}$ \\
\hline $\begin{array}{l}\text { Deoxypyridinoline (DPD, d-Pyr); high concentration } \\
\text { is observed only in bone tissue collagen; not found in } \\
\text { cartilage and skin; found only in mature collagen }\end{array}$ & Bone, dentine & Urine & $\begin{array}{l}\text { HPLC, } \\
\text { ELISA }\end{array}$ \\
\hline $\begin{array}{l}\text { Collagen type I N-terminal telopeptide (NTX); high levels } \\
\text { are found in bone collagen type I }\end{array}$ & $\begin{array}{l}\text { All tissues } \\
\text { which contain } \\
\text { collagen type I }\end{array}$ & $\begin{array}{l}\text { Urine, } \\
\text { serum }\end{array}$ & $\begin{array}{l}\text { ELISA, RIA, } \\
\text { ECLIA }\end{array}$ \\
\hline $\begin{array}{l}\text { Collagen type I C-terminal telopeptide } \\
(\alpha \text {-CTX fragments, } \beta \text {-CTX); high levels } \\
\text { are found in bone collagen type I }\end{array}$ & $\begin{array}{l}\text { All tissues } \\
\text { which contain } \\
\text { collagen type I }\end{array}$ & $\begin{array}{l}\text { Urine, } \\
\text { serum }\end{array}$ & $\begin{array}{l}\text { ELISA, RIA, } \\
\text { ECLIA }\end{array}$ \\
\hline \multicolumn{4}{|c|}{ Markers of collagen synthesis } \\
\hline C-terminal propeptide procollagen type I (PICP) & $\begin{array}{l}\text { Bone, skin, } \\
\text { soft tissues }\end{array}$ & Serum & RIA, ELISA \\
\hline N-terminal propeptide procollagen type I (PINP) & Bone, skin & Serum & RIA, ELISA \\
\hline
\end{tabular}

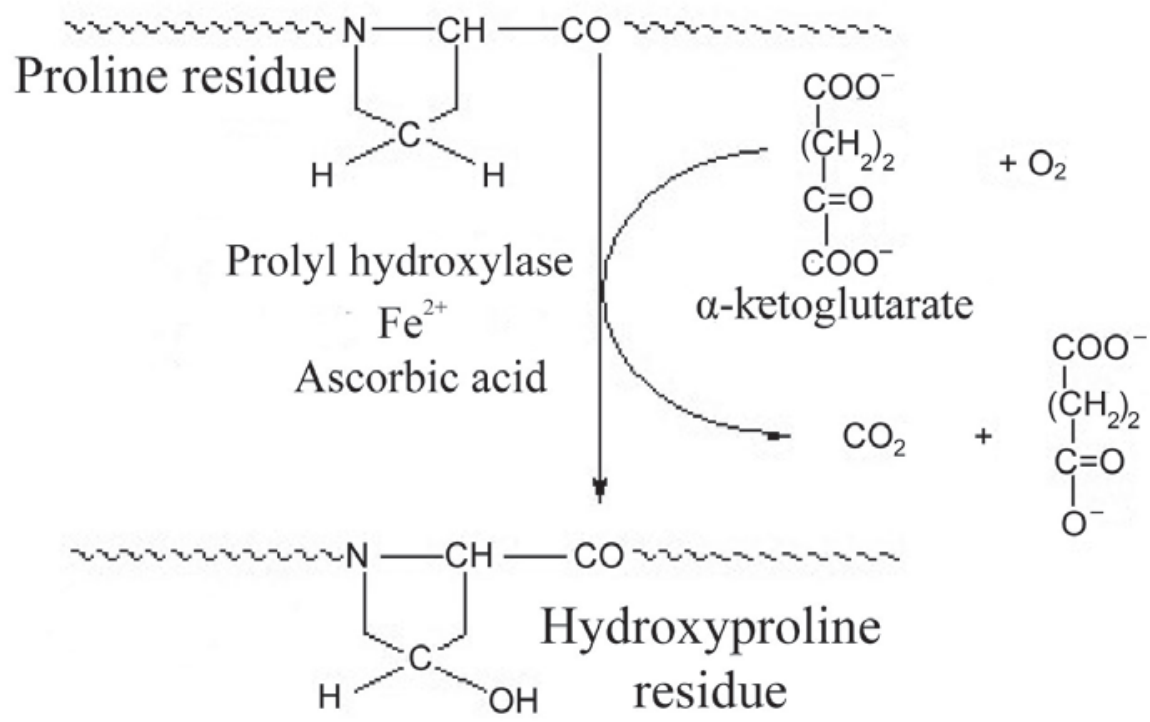

Fig. 2. Scheme of proline hydroxylation by prolyl hydroxylase 
resorption) circulates in plasma in the free amino acid form. After filtration and almost complete renal reabsorption, HYP is oxidized in the liver yielding urea and carbon dioxide. Approximately $10 \%$ of released HYP circulates in blood in the protein-bound form. These proteins are filtered and excreted into the urine without metabolic alterations [32, 33].

It is considered that collagen is one source of HYP in the body. Recently it was discovered that other animal proteins such as elastine, C1q, acetyl cholinesterase, glycoproteins obtained by lung lava ${ }^{-}$ ge also contain HYP [34]. Therefore, in case of HYP urine measurement the HYP contribution, released during non-collagenous proteins metabolism and procollagen type I N-terminal propeptide (PINP) should be considered. It also should be noted that HYP obtained from PINP images more bone formation than bone resorption [35]. Inflammation [36] and dietary collagen [35] can also lead to a significant HYP level increasing. Thus, total HYP urine level partly reflects collagen degradation.

Because of HYP availability in different proteins and due to its metabolism peculiarities the HYP level is weakly related with the actual bone collagen metabolism. All of these data indicate the necessity of using more sensitive and specific collagen type I degradation markers.

\section{Hydroxylysine (HYL)}

HYL is another modified amino acid that determines the unique collagen composition and proteins containing collagen-like sequences. Lysine hydroxylation occurs in the presence of lysyl hydroxylase. This process is necessary for the covalent bonds formation between collagen molecules in the fibrils' formation. The hydrocarbon residues, like galactose and galactosyl-glucose disaccharide, attach to the procollagen molecule after hydroxylation process. It is catalyzed by specific glycosyltransferases. As a result HYL is converted to galactosyl-hydroxylisine and glicosyl-galactosyl-hydroxylysine (Fig. 3) [12].

The relative and total content of galactosyl-hydroxylysine and glycosyl-galactosyl-hydroxylysine in bone and soft tissues are different. It allows suggesting that the urine glycosides' level is more sensitive marker of bone resorption and collagen molecule degradation as compared with the urine HYP [37].

Released HYL and HYP are not involved in collagen biosynthesis. Although HYL content in collagen is less than HYP content, but HYL is a prospective marker of this protein degradation. This marker needs further research $[37,38]$. (DPD)

3. Pyridinoline (PYD) and deoxypyridinoline

Deamination of lysine or hydroxylysine $\varepsilon$-amino group in the presence of lysyl oxidase leads to the cross-links formation with 3-hydroxypyridine ring in their structure (Fig. 4) [39, 27]. In human urine samples two types of cross-links are identified. There are DPD and PYD. These cross-links are formed during extracellular maturation of the fibril-

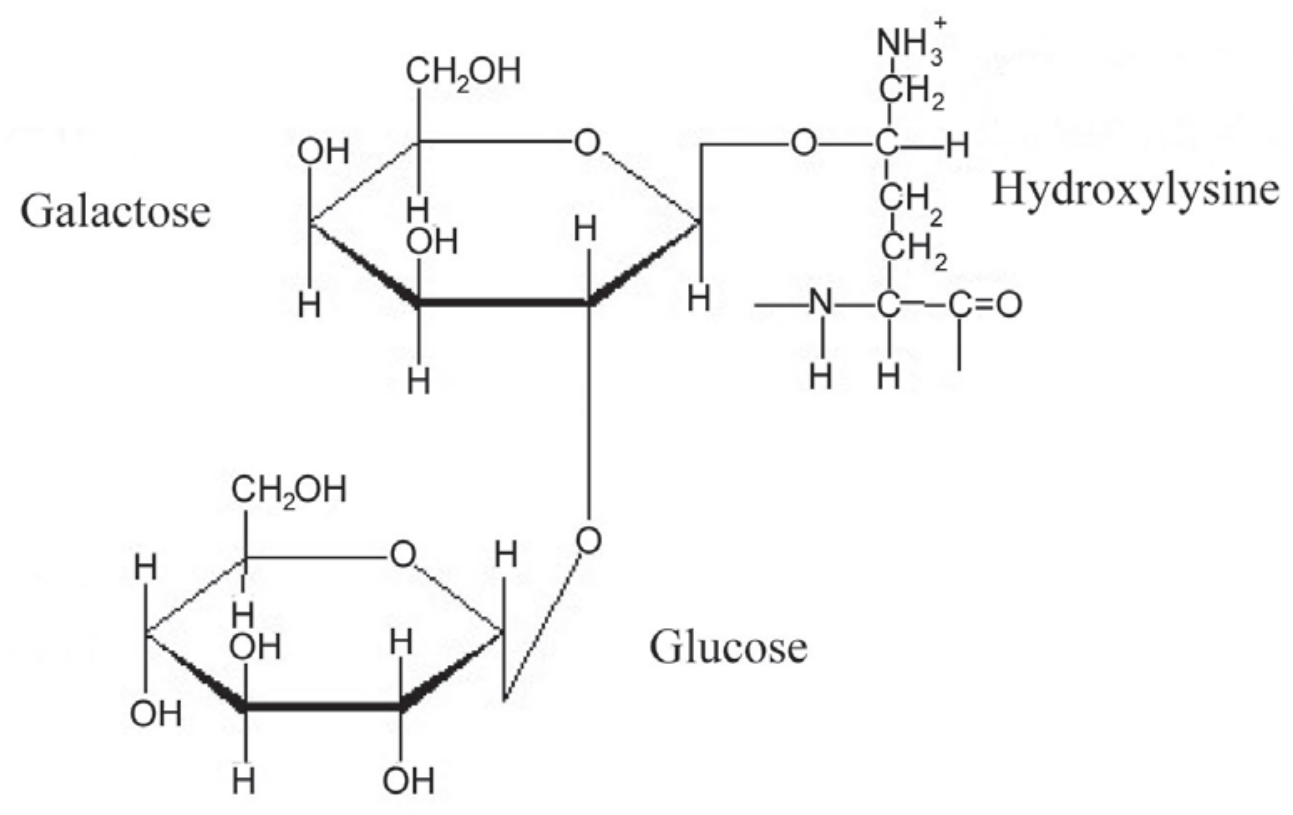

Fig. 3. Carbohydrate components of collagen 


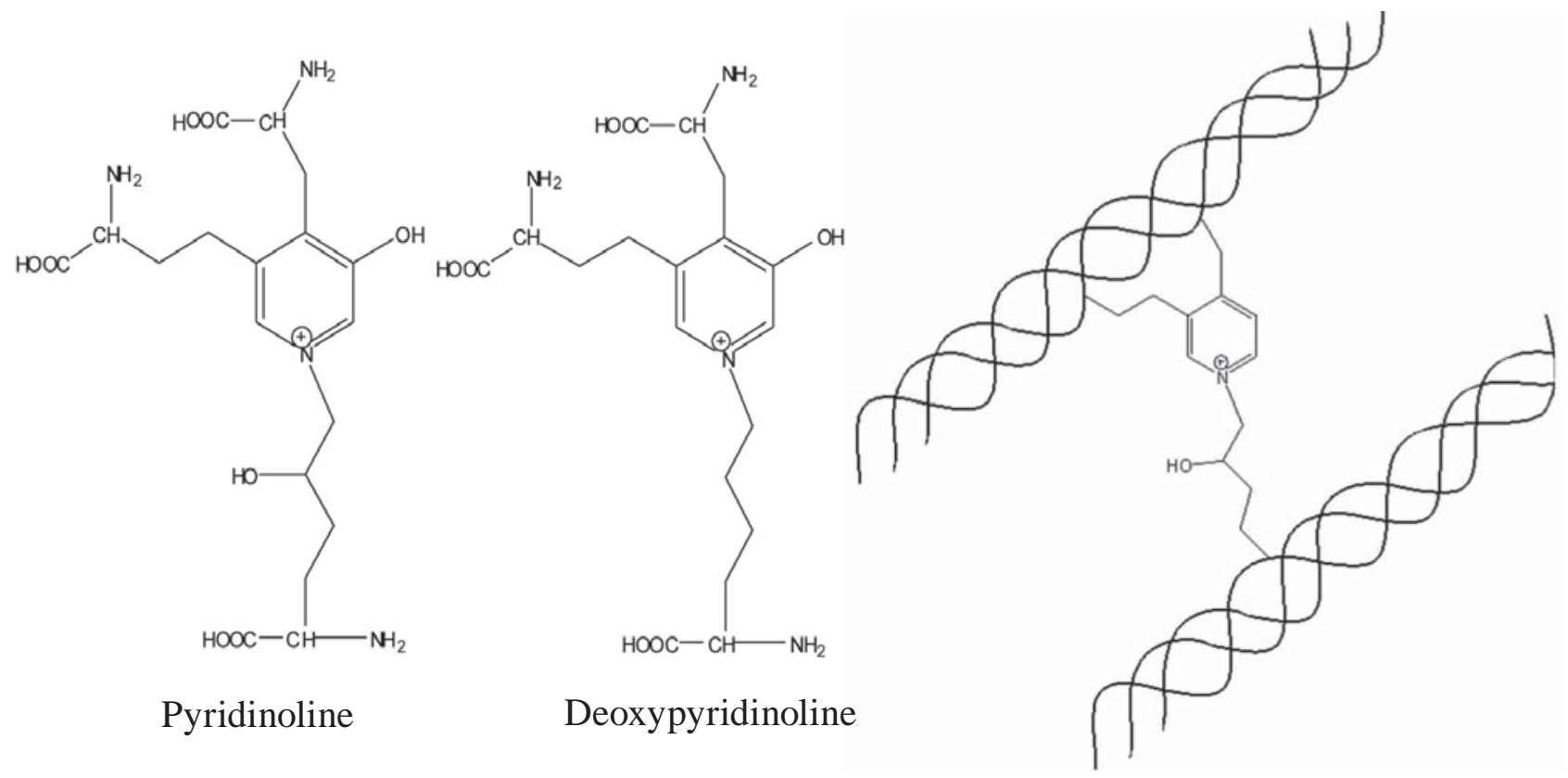

Fig. 4. Pyridine cross-links of collagen type I

lar collagens. Interaction between two hydrolysine and one lysine residues leads to the deoxypyridinoline formation. Pyridinoline cross-links are formed as a result of interaction between three hydrolysine residues of collagen molecule.

These cross-links stabilize the collagen structure. PYD and DPD ratio in human bone is about 3:4. PYD and DPD are formed during the posttranslational collagen modification which have been already secreted and incorporated into the extracellular matrix. That is why they cannot be directly reutilized for collagen synthesis [39].

High pyridinoline concentration is observed in the collagen type II of cartilage. Ppyridinoline has also been found in the bone collagen. The main deoxypyridinoline source is bone and dentin. Both DPD and PYD can be found in collagen tendon and aorta, but are not detected in the skin [40]. Because the major organic component of bone is collagen matrix, which has a rapid metabolic rate, it can be assumed that bone is the main source of PYD and DPD in biological fluids. Because DPD and PYD are formed during collagen molecule maturation they were considered as specific markers of bone resorption and collagen type I degradation [41].

PYD and DPD enter the bloodstream during bone collagen matrix proteolytic degradation. As low-molecular-weight compounds, they are excreted with urine in free (40\%) or peptide-bound form
(60\%) [42]. DPD and PYD excretion is controlled by circadian rhythm: the highest excretion occurs at night and the lowest - in the day time [43]. Some other factors can also affect the PYD and DPD level in the urine. It may increase 2 times during pregnancy. The urine DPD excretion for females in menopause is 2-3 times higher than for females in fertile age. Diet and physical activity have no effect on DPD and PYD excretion. Urine DPD level is higher for females than for males. For both sexes PYD and DPD content in the urine increases in cases of primary hyperparathyroidism (about 3 times) [43], hyperthyroidism (about 5 times) and Paget's disease (12 times). Also significant increasing of DPD excretion is observed in cases of osteoporosis, osteoarthritis and rheumatoid arthritis [44].

The determination of pyridine cross-links level in the urine has several potential advantages. There are high specificity of pyridine cross-links for bone turnover, absence of DPD and PYD metabolic transformation in vivo before the urine excretion and their determination without any prior dietary limitations [45].

The urine DPD and PYD content can be determined by the HPLC analysis, ELISA fluorometric and chemiluminescent methods. In particular, ELISA is the most commonly used method that allows determining free DPD and PYD form. However, these results should be accompanied by other 


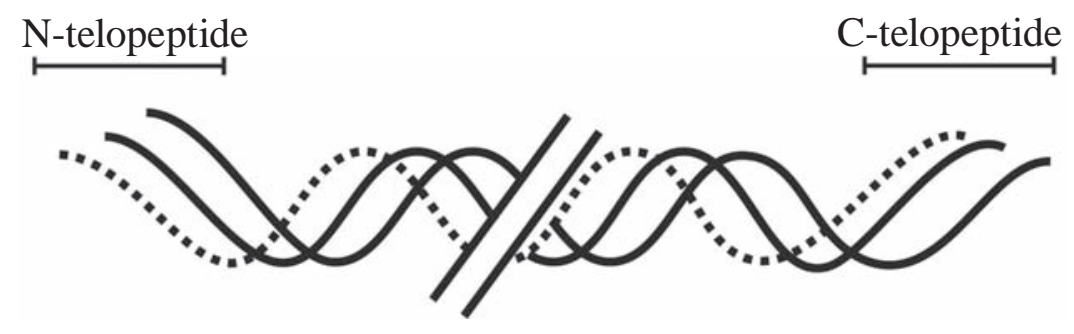

Fig. 5. Localization of $\mathrm{N}$ - and C-telopeptide in the collagen type I

diagnostic tests, because the DPD and PYD content in the urine does not fully characterize normal or pathological bone state [19, 45].

4. Collagen type I telopeptides (CTX, NTX)

Fragments of carboxy- (CTX) and amino(NTX) terminal collagen cross-links are released in the bloodstream as a result of osteoclast-mediated collagen type I degradation. It occurs under bone resorption by action of osteoclasts proteolytic enzyme cathepsin K. As compounds with small size, they are readily pass through the glomerulus and excreted with urine (Fig. 5) [19].

NTX fragments can be identified in the serum and urine. NTX level is significantly decreased after the anti-resorptive therapy. It is currently unclear the influence of diet on the NTX level. Monoclonal antibodies for NTX determination that specifically recognize the $\alpha-2$ chain $N$-telopeptide fragment are used in clinics [19]. CTX fragments in the urine also can be determined by ELISA.

After racemization and isomerization $\alpha$-CTX can form to $\beta$-CTX ( $\alpha$-aspartic acid is converted to $\beta$-form). That is why monoclonal antibodies which can specifically recognize $\alpha$ - or $\beta$-CTX are used [46]. $\alpha$-CTX indicates the breakdown of the newlysynthesized collagen while $\beta-C T X$ of the mature collagen. Based on these data it is proposed to calculate the $\alpha-C T X / \beta-C T X$ ratio and use obtained index as a value of bone metabolism rate. E.g., $\alpha$-CTX/B-CTX index is increased in patients with Paget's disease and rapidly decreased under the biophosphonates influence. This index in serum is increased almost 2 times during menopause [46].

Because osteoclasts affect only bone collagen type I CTX and NTX fragments are the most informative markers of bone collagen destruction $[47,48]$. Thus, determination of CTX and NTX level in dynamics is used for bone diseases diagnosing and bone resorption monitoring during antiresorptive therapy. These markers allow evaluating the efficacy of bone diseases therapy after 3 months of treatment [26].

\section{Markers of type I collagen formation}

1. Procollagen type I terminal propeptides (PINP, PICP)

During extracellular collagen type I maturation (before fibrils' formation) the N-terminal (PINP) and C-terminal (PICP) propeptides are removed from procollagen molecule by specific endopeptidase. Procollagen molecule is by $50 \%$ longer than mature collagen. Propeptides removing is necessary for early collagen molecule aggregation into fibrils inside the cells.

Procollagen type I C-terminal propeptide is a glycoprotein $\left(\mathrm{M}_{\mathrm{r}} 115 \mathrm{kDa}\right)$ which is composed of three polypeptide chains. There are two $\alpha 1-\mathrm{I}$ polypeptide chains, containing 246 amino acid residues and one $\alpha 2-I$ polypeptide chain, containing 247 amino acid residues. Each of these chains contains oligosaccharides with high mannose content. Intraand intermolecular disulfide bonds aggregate subunits with a globular structure formation (Table 2) [26]. This structure is necessary for the normal triple structure formation of mature collagen type I molecules.

Due to the high mannose content, PICP is metabolized in the liver endothelial cells by means of the mannose-6-P receptors. PICP half-life is about 6-8 minutes [49, 50].

Procollagen type I N-terminal propeptide $\left(M_{r} 70 \mathrm{kDa}\right)$ is a heterotrimer without covalent bounds in its triple structure. PINP is composed of two $\alpha 1-I$ polypeptide chains and one $\alpha 2-$ I chain. These chains are held together by identical to the collagen molecule structure short helical sites. These collagen-like sites define PINP properties. Thus, PINP antigenicity is increased at its interaction with a small helical domain of $\alpha 1-\mathrm{I}$ chain Col-1, which is the most immunogenic part of PINP propeptide [50]. PINP is metabolized by livers' macrophages and its blood level is 100 times higher than the PICP concentration $[44,50]$. 
Ta b le 2. Comparative characteristics of procollagen type I propeptides

\begin{tabular}{lcc}
\hline \multicolumn{1}{c|}{ Propeptides } & PINP & PICP \\
\hline Localization & aminoterminal & carboxyterminal \\
Molecular weight & $70 \mathrm{kDa}$ & $115 \mathrm{kDa}$ \\
Structure & linear & globular \\
Chemical nature & phosphoprotein & glycoprotein \\
Bonds & non-covalent & disulfide \\
\hline
\end{tabular}

The maturation of soft tissue collagen type I can contribute to the total level of PINP and PICP. However, this contribution has the minimum value, because the main part of PINP and PICP is released during bone collagen type I formation. The ratio between collagen, which is deposited in bone matrix and PICP (or PINP), which is released into the bloodstream, are theoretically equal to 1 . Thus, based on blood propeptides' level, it is possible to characterize the ability of osteoblasts to synthesize collagen type I. As propeptides with high molecular weight, PINP and PICP cannot be filtered through the kidney. So, their level is not affected by kidney filtration [27].

High level of PICP and PINP is observed in pathologies associating with increased bone remodeling processes in particular Paget's disease, hyperthyroidism, primary hyperparathyroidism and neurogenic osteodystrophy. In some cases, elevated PICP level is observed in early menopause. Low PICP concentrations are found in children with growth hormone deficiency [51].

Data from numerous investigations indicate that PINP and PICP reflect bone tissue formation. That is why PINP and PICP are significant markers for monitoring bone diseases [26, 51].

Biochemical markers of bone synthesis and degradation are an important tool for assessing and monitoring skeletal system conditions. As compared with standard clinical methods, determination of the potential new bone metabolism markers allows investigating the rate of bone metabolism and spontaneous bone loss, performing the bone diseases monitoring and prognosis of the risk of fractures. Besides the main markers of mineral metabolism, synthesis and degradation of collagen type I (CTX, NTX, PINP, PICP, GP, GL, DPD, PYD), new markers of bone remodeling have been discovered. These include periostin (POSTN), osteocytes' factors: sclerostin and FGF-23, circulating in blood microRNA (miRNA) [44].
Periostin is a Gla-containing extracellular matrix protein. Periostin is located in the periosteum and affects the regulation of bone formation and its strength through the PYD and DPD cross-links formation in collagen [52]. Sklerostin stimulates secretion of RANK-L which is formed in osteocytes. Sklerostin also enhances osteoclasts' activity. Circulating factor FGF-23 which is expressed in osteocytes, negatively affects the serum levels of inorganic phosphate and 1,25-dihydroxyvitamin $\mathrm{D}_{3}$ [53]. MicroRNAs play a significant role in normal differentiation and functioning of the bone cells [54].

Thus, many new biomarkers of bone tissue remodeling have been recently discovered and investigated. Their use along with well-studied markers will allow detecting and preventing numerous bone diseases.

\section{БIОХIМІЧНI МАРКЕРИ МЕТАБОЛІЗМУ КОЛАГЕНУ І ТИПУ КІСТКОВОЇ ТКАНИНИ}

\section{О. В. Зайцева, С. Г. Шандренко, М. М. Великий}

\author{
Інститут біохімії ім. О. В. Палладіна \\ НАН України, Київ; \\ e-mail: Zaitseva_OV@ukr.net
}

В огляді проведено аналіз діагностичного значення основних маркерів ремоделювання кісткової тканини, зокрема, синтезу та деградації колагену I типу, до яких належать карбокси- та амінотермінальні телопептиди, карбокси- та амінотермінальні пропептиди проколагену I типу, гідроксипролін, гідроксилізин, піридинолін та дезоксипіридинолін. Їх визначення дозволяе оцінити структурнофункціональний стан та швидкість обмінних процесів у кістковій тканині. Розглянуто переваги та недоліки методів визначення цих маркерів за різних кісткових захворювань. Показано, що 
визначення маркерів метаболізму колагену I типу кісткової тканини $є$ найінформативнішим для оцінки кісткової резорбції, формування та ремоделювання.

К л ю ч о в і с л о в а: колаген I типу, маркери синтезу та деградації колагену, кісткова тканина.

\section{БИОХИМИЧЕСКИЕ МАРКЕРЫ МЕТАБОЛИЗМА КОЛЛАГЕНА I ТИПА КОСТНОЙ ТКАНИ}

\author{
О. В. Зайцева, С. Г. Шандренко, \\ Н. Н. Великий
}

\author{
Институт биохимии им. А. В. Палладина \\ НАН Украины, Киев; \\ e-mail: Zaitseva_OV@ukr.net
}

В обзоре проведен анализ диагностического значения основных маркеров ремоделирования костной ткани, в частности, синтеза и деградации коллагена I типа. К ним относятся карбокси- и аминотерминальные телопептиды, карбокси- и аминотерминальные пропептиды проколлагена I типа, гидроксипролин, гидроксилизин, пиридинолин и дезоксипиридинолин. Их определение позволяет оценить структурнофункциональное состояние и скорость обменных процессов в костной ткани. Рассмотрены преимущества и недостатки методов определения этих маркеров при различных костных заболеваниях. Показано, что определение маркеров метаболизма коллагена I типа костной ткани является наиболее информативным для оценки костной резорбции, формирования и ремоделирования.

К лючевы е с лова: коллаген I типа, маркеры синтеза и деградации коллагена, костная ткань.

\section{References}

1. Gayko G. V., Kalashnikov An. V., Brusko A. T., Apukhovska L. I., Kalashnikov Al. V. Vitamine D and bone system. Kyiv: Book plus, 2008. 176 p. (In Russian).

2. Veliky M. M., Zaytseva O. V., Shymanskyy I. O., Shandrenko S. G., Latyshko N. V., Gudkova O. O., Mazanova A. O., Apukhovska L. I. The features of biomolecule peroxidation processes in rat liver under conditions of vitamin $\mathrm{D}_{3}$ deprivation. Biol. Systems. 2013;5(3):287-294. (In Ukrainian).
3. Komisarenko S. V., Apukhovska L. I., Riasniy V. M., Kalashnikov A. V., Veliky N. N. "Mebivid" biopharmaceutical preparation efficacy against vitamin $\mathrm{D}_{3}$ and calcium metabolism disorders in alimentary osteoporosis. Biotechnol. Acta. 2011;4(1):74-81. (In Ukrainian).

4. Blackwell P., Godber I. M., Lawson N. Biochemical markers of bone turnover. - In: Clinical Trials in Osteoporosis (Second Edition) / D. Pearson, C. J. Miller (Eds.). London: SpringerVerlag, 2007:247-269.

5. Riggs B. L., Melton L. J. Osteoporosis etiology, diagnosis, and management. M.: Binom, 2000. $560 \mathrm{p}$.

6. Lee J. A., Hodges S., Eastell R. Measurment of osteocalcin. Ann. Clin. Biochem. 2000;37:432446.

7. Bebeshko V. G., Bruslova K. M., Panchenko L. M., Volodina T. T., Astachova V. S., Stvetkova N. M., Mishchenko L. P., Trychlib I. V. Influence of bone marrow colony forming fibroblasts units (CFFU) efficiency on disease-free life expectancy for children with acute lymphoblastic leukemia. Ukr. J. Hematol. Blood Transfus. 2010;10(6):5-7. (In Ukrainian).

8. Civitelli R. Biochemical markers of bone turnover. In: The Osteoporotic Syndrome. Detection, prevention, and treatment (Fourth Edition)/ L. V. Avioli (Ed.). New York: Academic Press, 2000. P. 67-89.

9. Volodina T. T., Pechenova T. M., Dzvonkevich N. D., Popova N. N., Silonova N. V., Astahova V. S., Panchenko L. M., Guly M. F., Mikhaylovsky V. O. Modifying effect of low-molecular metabolities on the state of extracellular matrix of connective tissue of animals. Ukr. Biokhim. Zhurn. 2007;79(6):65-73. (In Ukrainian).

10. Kini U., Nandeesh B.N. Physiology of bone formation, remodeling, and metabolism. Radionuclide and Hybrid Bone Imagine. 2012;XIV:29-57.

11. Jayachandran V., Se-Kwon K. Chitosan composites for bone tissue engineering - An Overview. Mar. Drugs. 2010;8(8):2252-2266.

12. Shoulders M. D., Raines R. T. Collagen structure and stability. Ann. Rev. Biochem. 2009;78:959958.

13. Gelse K., Poschl E., Aigner T. Collagens structure, function, and biosynthesis. Adv. Drug Deliv. Rev. 2003;55:1531-1546. 
14. Viguet-Carrin S., Garnero P., Delmas P. D. The role of collagen in bone strength. Osteoporos. Int. 2006:17:319-336.

15. Trammel L. H., Kroman A. M. Bone and dental histology. In: Research Methods in Human Skeletal Biology / E. A. Di Gangi, M. K. Moore (Eds.). Elsevier Inc., 2013. P. 361-395.

16. Kramer R. Z., Bella J., Brodsky B., Berman H. M. The crystal and molecular structure of a collagen-like peptide with a biologically relevant sequence. J. Mol. Biol. 2001;311(1):131-147.

17. Knupp C., Squire J. M. Molecular packing in network-forming collagens. Sci. World J. 2003;3:558-577.

18. Saeidi N., Karmelek K. P., Ruberty J. A. Molecular crowding of collagen: A pathway to produce highly-organized collagenous structures. Biomaterials. 2012;33(30):7366-7374.

19. Shaw N., Högler W. Biochemical markers of bone metabolism. In: Pediatric Bone (2nd Ed.) / H. F. Glorieux, J. M. Pettifor, H. Juppner (Eds.). 2012. P. 361-381.

20. Paolino D., Cosco D., Cilurzo F., Trapasso E., Morittu V. M., Celia C., Fresta M. Improved in vitro and in vivo collagen biosynthesis by asiaticoside-loaded ultradeformable vesicles. J. Control. Release. 2012;162(1):143-151.

21. Ono S., Imai T., Shimizu N., Nakayama M., Yamano T., Tsumura M. Serum markers of type I collagen synthesis and degradation in amyotrophic lateral sclerosis. Eur. Neurol. 2000;44(1):49-56.

22. Ricarrd-Blum S., Ruqqiero F. The collagen superfamily: from the extracellular matrix to the cell membrane. Pathol. Biol. 2005;53(7):430442.

23. Prokop D. J., Sieron A. L., Li S. W. Procollagen $\mathrm{N}$ - proteinase and procollagen C-proteinase. Two unusual metaloproteinases that are essential for procollagen processing probably have important roles in development and cell signaling. Matrix Biol. 1998;16(7):399-408.

24. Jensen C. H., Hansen M., Brandt J., Rasmussen H. B., Jensen P. B., Teisner B. Quantification of the N-terminal propeptide of human procollagen type I (PINP): Comparison of ELISA and RIA with respect to different molecular forms. Clin. Chim. Acta. 1998;269(1):31-41.

25. Parsons M., Kessler E., Laurent G. J., Brown R. A., Bishop J. E. Mechanical load enhances procollagen processing in dermal fibroblasts by regulating levels of procollagen C-proteinase. Exp. Cell Res. 1999;252(2):319331.

26. Čepelak I., Čvorišćec D. Biochemical markers of bone remodeling - review. Biochemia Medica. 2009;19( 1):17-35.

27. Seibel M. J. Biochemical markers of bone turnover part I: Biochemistry and Variability. Clin. Biochem. Rev. 2005;26(4):97-122.

28. Shiqemura Y., Kubomura D., Sato Y., Sato K. Dose-dependent changes in the levels of free and peptide forms of hydroxyproline in human plasma after collagen hydrolysate ingestion. Food Chem. 2014;159(15):328-332.

29. Gorres K. L., Raines R. T. Prolyl 4-hydroxylase. Crit. Rev. Biochem. Mol. Biol. 2010;45(2):106124.

30. Babeshko V. G., Bruslova K. M., Kusher O. V., Babeshko O. V., Volodina T. T. Assessment of bone tissue condition under the amino acid composition of urine. Ukr. J. Hematol. Blood Transfus. 2009;(2):24-26. (In Ukrainian).

31. Ignat'eva N. Yu., Danilov N. A., Averkiev S. V., Obrezkova M. V., Lunin V. V., Sobol E. N. Determination of hydroxyproline in tissues and the evaluation of the tissues. J. Anal. Chemistry. 2007;62(1):51-57.

32. Jagtap V. R., Ganu J. V. Effect of antiresorptive therapy on urinary hydroxyproline in postmenopausal osteoporosis. Indian J. Clin. Biochem. 2012;27(1):90-93.

33. Atlante A., Passarella S., Quagliariello E. Spectroscopic study of hydroxyproline transport in rat kidney mitochondria. Biochem. Biophys. Res. Commun. 1994;202(1):58-64.

34. Volodina T. T., Pechenova T. M., Petrun L. M., Alesina M. U. Condition of bone connective tissue matrix and coating tissue of rats under combined exposure. Kyiv: Atika, 2006. P. $145-$ 156. (In Ukrainian).

35. Hess B. J., Johnston M. M., Iobst W. F., Lipner R. S. Practice-based learning can improve osteoporosis care. J. Am. Geriatr. Soc. 2013;61(10):1651-1660.

36. Millet P., Vilaseca M.A., Valls C., PérezDueñas B., Artuch R., Gomez L., Lambruscihini N., Campistol J. Is deoxypyridinoline a good resorption marker to detect osteopenia in phenylketonuria? Clin. Biochem. 2005;38(12):1127-1132.

37. Lo Cascio V., Bertoldo F., Gambaro G., Gasperi E., Furlan F., Colapietro F., Lo 
Cascio C., Campaqnola M. Urinary galactosylhydroxylysine in postmenopausal osteoporotic women: A potential marker of bone fragility. J. Bone Miner. Res. 1999;14(8):1420-1424.

38. Langrock T., Garcia-Villar N., Hoffman R. Analysis of hydroxyproline isomers and hydroxylysine by reversed-phase HPLC and mass spectrometry. J. Chromatography. B, Analyt. Technol. Biomed. Life Sci. 2007;847(2):282-288.

39. Eriksen H. A., Sharp C. A., Robins S. P., Sassi M. L., Risteli L., Risteli J. Differently cross-linked and uncross-linked carboxyterminal telopeptides of type I collagen in human mineralised bone. Bone. 2004;34(4):720-727.

40. Stevenson D. A., Schwarz E. L., Viskochil D. H., Moyer-Mileur L. J., Murray M., Firth S. D., D’Astous J. L., Carey J. C., Pasquali M. Evidence of increased bone resorption in neurofibromatosis type 1 using urinary pyridinium crosslink analysis. Pediatr. Res. 2008;63(6):697-701.

41. Seibel M., Woitge W. Basic principles and clinical applications of biochemical markers of bone metabolism: Biochemical and technical aspects. J. Clin. Densitom. 1999;2(3):299-321.

42. Vesper H. W., Audain C., Woolfitt A., Ospina M., Barr J., Robins S. P., Mayers G. L. Highperformance liquid chromatography method to analyze free and total urinary pyridinoline and deoxypyridinoline. Anal. Biochem. 2003;318(2):204-211.

43. Fassbender W. J., Gödde M., Brandenburg V. M., Usadel K. H., Stumpf U. C. Urinary bone resorption markers (deoxypyridinoline and C-terminal telopeptide of type I collagen) in healthy persons, postmenopausal osteoporosis and patients with type I diabetes. Adv. Med. Sci. 2009;54(1):1-6.

44. Garnero P. New developments in biological markers of bone metabolism in osteoporosis. Bone. 2014;(66):46-55.

45. Abe Y., Ishikawa H., Fukao A. Higher efficacy of urinary bone resorption marker measurements in assessing response to treatment for osteoporosis in postmenopausal women. Tohoku J. Exp. Med. 2008;214(1):51-59.
46. Civitelli R., Armamento-Villareal R., Napoli N. Bone turnover markers: understanding their value in clinical trials and clinical practice. Osteoporos. Int. 2009;20(6):843-851.

47. Tanzy M. E., Camacho P. M. Effect of vitamin $\mathrm{D}$ therapy on bone turnover markers in postmenopausal women with osteoporosis and osteopenia. Endocr. Pract. 2011;17(6):873-879.

48. Baim S., Miller P.D. Assessing the clinical utility of serum CTX in postmenopausal osteoporosis and its use in predicting risk of osteonecrosis of the jaw. J. Bone Miner. Res. 2009;24(4):561-574.

49. Smedsrod B., Melkko J., Restelli L., Restelli J. Circulating C-terminal propeptide of type I procollagen is cleared mainly via the mannose receptor in liver endothelial cells. Biochem. $J$. 1990;271(2):345-350.

50. Risteli J., Niemi S., Kauppila S., Melkko J., Risteli L. Collagen propeptides as indicators of collagen assembly. Acta Orthop. Scand. 1995;66(266):183-188.

51. Leeming D. J., Koizumi M., Qvist P., Barkholt V., Zhang C., Henriksen K., Byrjalsen I., Karsdal M. A. Serum N-terminal propeptide of collagen type I is associated with the number of bone metastases in breast and prostate cancer and correlates to other bone related markers. Biomark Cancer. 2011;3:15-23.

52. Li X., Zhang Y., Kang H., Liu W., Liu P., Zhang J., Harris S. E., Wu D. Sclerostin binds to LRP5/6 and antagonizes canonical Wnt signaling. J. Biol. Chem. 2005;280(20):19883-19887.

53. Shimada T., Hasegawa H., Yamazaki Y., Muto T., Hino R., Takeuchi Y., Fujita T., Narahara K., Fukumoto S., Yamashita T. FGF23 is a potent regulator of vitamin D metabolism and phosphate homeostasis. J. Bone Miner. Res. 2004;19(3):429-435.

54. Lian J. B., Stein J. S., van Wijnen A.J., Stein J. L., Hassan M. Q., Gaur T., Zhanq Y. Micro RNA control of bone formation and homeostasis. Nat. Rev. Endocrinol. 2012;8(4):212-227.

Received 15.07.2014 